\title{
Małgorzata Gajak-Toczek
}

Uniwersytet Łódzki

DOI 10.19195/1642-5782.16(26).2

\section{Język domostwem bycia o funkcjonalnym nauczaniu polszczyzny w podręcznikach dla nauczycieli Tadeusza Czapczyńskiego}

Priorytetowym zadaniem, z którym musieli zmierzyć się reformatorzy polskiej oświaty po 1918 r., było zorganizowanie i ujednolicenie systemu edukacji we wszystkich dzielnicach kraju. Patronat nad działaniami objęło Ministerstwo Wyznań Religijnych i Oświecenia Publicznego, które przygotowywało i wdrażało projekty ustaw oraz plany nauczania. Na kierunki zmian metod kształcenia wpływały ruchy reformatorskie $\mathrm{z}$ terenów byłego zaboru austriackiego ${ }^{1} \mathrm{i}$ ziem Królestwa Polskiego ${ }^{2}$. Inspiracją były także prace polskich, europejskich i amerykańskich badaczy z zakresu językoznawstwa ${ }^{3}$, psychologii, pedagogiki, socjolo-

${ }^{1}$ Zob. na ten temat: M. Gajak-Toczek, Franciszek Próchnicki (1847-1911) - dydaktyk - edytor — badacz literatury, Łódź 2010; Sylwetki lwowskich historyków literatury, red. J. Starnawski, Łódź 1997.

${ }^{2}$ Zob. Prądy w nauczaniu języka polskiego, [praca zbiorowa], Warszawa 1908.

${ }^{3}$ Prace polskich badaczy podaję w porządku alfabetycznym: J. Baudouin de Courtenay, Znaczenie języka jako przedmiotu nauki szkolnej, [w:] Prady w nauczaniu..., s. 1-12; H. Gaertner, Nauka o języku polskim. Wskazówki do samokształcenia ze słowniczkiem terminów gramatycznych i pomocniczych, Lwów 1927; Z. Klemensiewicz, Dydaktyka nauki o języku ojczystym. Zasady i zagadnienia, Warszawa 1928; J. Łoś, Gramatyka polska, t. 1-3, Lwów 1922-1926; K. Nitsch, Kilka słów o celach nauczania języka ojczystego, „Rocznik Pedagogiczny” 1, 1921, s. II, 190-194, przedruk [w:] Wybór prac z metodyki nauczania języka polskiego, red. B. Wieczorkiewicz, Warszawa 1964, s. 24-27; J. Rozwadowski, O nauce języka ojczystego w szkołach i o rzeczach pokrewnych, „Język Polski” 1926, nr 1, s. 1-20; M. Rudnicki, Wyksztatcenie językowe w życiu i szkole, Warszawa-Poznań 1920; S. Szober, Pogląd na świat w odbiciu faktów językowych $i$ wartości wychowawcze nauki gramatyki, „Rocznik Pedagogiczny” 1921, s. II, s. 194-213; idem, Zasady nauczania języka polskiego w zakresie szkoły powszechnej i gimnazjum niższego, Lwów-Warszawa 1921; idem, Gramatyka $w$ szkole średniej. Jej zadania, metoda, program, teoria i zakres wykładu, „Wychowanie 
gii, logiki i teorii poznania. Badacze ci postulowali stworzenie takich warunków, by wychowanek — z biernego odtwórcy treści przekazywanych na lekcji — stał się aktywnym uczestnikiem procesu nauczania i uczenia się.

Dydaktyka języka polskiego zawdzięcza Tadeuszowi Czapczyńskiemu ${ }^{4}$ nowatorską na ówczesne czasy funkcjonalną koncepcję nauczania języka, przedstawioną w pracach: Ćwiczenia w mówieniu. Przyczynek do metodyki języka polskiego ${ }^{5}$ oraz Metodyka ćwiczeń stylistycznych w szkole powszechnej i średniej.

w Domu i Szkole" 1913, nr 3, s. 198-209; nr 4, s. 302-315; nr 5, s. 417-436; idem, Znaczenie pedagogiczno-wychowawcze języka ojczystego jako przedmiotu wykładowego, „Nowe Tory” 1, 1911, z. 5, przedruk [w:] Wybór prac z metodyki..., s. 18-23; J. Woroniecki, Około kultu mowy ojczystej, Lwów-Warszawa 1925.

${ }^{4}$ T. Czapczyński (ur. 1884 we Lwowie, zm. w 1958 w Łodzi) — polonista, badacz literatury i twórca. U progu niepodległości przedstawił model heurystycznego poznawania dzieła literackiego na przykładzie Pana Tadeusza Mickiewicza (1920, 1922, 1925) oraz Ogniem i mieczem Sienkiewicza (1922). Autor wielu studiów literackich [Twórczość powieściopisarska Józefa Weyssenhoffa (jednostronna analiza wewnętrznej konstrukcji), [w:] Sprawozdanie dyrekcji gimnazjum realnego żeńskiego Sióstr Urszulanek w Stanisławowie z prawem publiczności w myśl reskr. Min. W. i O. z 16 maja 1914, L. 18574 oraz Szkoły Pospolitej i Liceum 7-klasowego za rok szkolny 1913/14, Stanisławów 1914, s. 3-45; Marian Piechal (1937); Ze studiów nad pieśniq o Pitsudskim (1939)], prac biograficznych ad usum scholarum [Walerian Eukasiński (1913); Aleksander Fredro (1947); Hugo Koltątaj (1948)] oraz artykułów metodycznych [Lekcja metodyczna: ,, Gtupi Franek” Konopnickiej, „Muzeum” 1922, z. 2, s. 123-150; Pierwszy ustęp w klasie pierwszej szkoty średniej (cz. II), „Przyjaciel Szkoły” 1924, nr 14, s. 296-300], szkiców na temat dorobku Marii Dąbrowskiej i Marii Konopnickiej, a także niewydanej monografii tej ostatniej. Był popularyzatorem dorobku romantyków oraz autorem własnych wierszy (Pamiętam... Poezje, 1938) i książeczek dla dzieci (Książeczka trochę nowa, trochę stara o Magdzie, mace, kluskach i zegarach, 1942; Idzie sobie bobas maty, 1948). Zob. S. Skwarczyńska, Tadeusz Czapczyński (1884-1958), „Prace Polonistyczne” 1960, seria 16, s. 229-232; B. Bogołębska, Czapczyński Tadeusz (1884-1958), [w:] Słownik badaczy literatury polskiej, red. J. Starnawski, Łódź 1994, s. 55-61; J. Czachowska, Czapczyński Tadeusz, [w:] Wspótcześni polscy pisarze i badacze literatury. Stownik biobibliograficzny, oprac. J. Czachowska, A. Szałagan, t. 2, Warszawa 1994, s. 80-82; M. Gajak-Toczek, Tadeusz Czapczyński. Pedagog literaturoznawca - literat, Łódź 2017.

5 T. Czapczyński, Ćwiczenia w mówieniu. Przyczynek do metodyki języka polskiego, Warszawa 1922 (dalej skrót ĆW i nr strony). Publikacja składała się z czterech rozdziałów: I — Uwagi wstępne, w których Czapczyński przedstawił cele nauczania języka polskiego ze szczególnym zaakcentowaniem teleologii ćwiczeń w mówieniu w kontekście ich historycznego rozwoju; II Zainteresowania młodzieży szkolnej, gdzie przybliżył fazy rozwojowe dziecka w odniesieniu do ustaleń europejskiej i polskiej myśli psychologicznej i pedagogicznej oraz wskazywał konieczność uwzględniania jego możliwości psychofizycznych w projektowaniu wszelkich czynności procesu dydaktycznego; za ważny czynnik w aktywizowaniu wychowanków badacz uznał ich zainteresowania (przywołał m.in. prace. É. Claparède'a, L. Nagya, A. Szycówny, H. Rowida, J.W. Dawida); III — Zastosowania praktyczne zawierały propozycje ćwiczeń z podziałem na zagadnienia i formy stosowne do poszczególnych klas; IV — Dodatek — tu polonista zamieścił wykaz tematów, mów i kompozycji sugerowanych przez Komisję Edukacji Narodowej. Czapczyński jest także autorem wypowiedzi: Wypracowania piśmienne w świetle pogląów niemieckich (1911-1930). Karta z historii zagadnienia, „Prace Polonistyczne” 1938, seria 2, s. 329-350, oraz Wypracowania piśmienne w świetle pogladów niemieckich (1911-1930). Tematy wypracowań, „Prace Polonistyczne” 1939, seria 3, s. 363-382, odbitka: Łódź 1939, ss. 22.

Kształcenie Językowe 16 (26), 2018

(C) for this edition by CNS 
Podręcznik dla nauczyciela ${ }^{6}$. Celem artykułu jest przybliżenie sposobów, za których pomocą międzywojenny pedagog, jako zwolennik integrowania kształcenia literackiego (literaturę uznawał za wzór zachowań językowych w różnych sytuacjach komunikacyjnych) z językowym (nastawienie komunikatu na odpowiedni składnik: nadawca, odbiorca, cel przekazu), procedury opisowo-interpretacyjne stylistyki czynił narzędziem interpretowania tekstu (funkcjonalność poznanych struktur) oraz doskonalenia niezbędnych w codziennym życiu człowieka umiejętności mówienia i pisania.

\section{Uczyć języka inaczej}

Szczegółową prezentację publikacji Czapczyńskiego warto poprzedzić przypomnieniem różnorodnych stanowisk dotyczących celów, zakresu i metodologii stylistyki - tym bardziej, że na przełomie XIX i XX w. ukonstytuowały się jej naukowe podstawy ${ }^{7}$. Różnie jednak definiowano jej treść i zakres. Encyklopedie i słowniki polskie międzywojnia „styl”" ujmowały jako indywidualny sposób wypowiedzi autora, a stylistyce - choć traktowano ją dalej jako naukę o środkach wyrażania uczuć i myśli - wyznaczano nowe zadania i wprowadzano nowe metody. Powszechnie przekonywano, że ,podstawą badań stylistycznych jest wyodrębnienie, indywidualizacja, szukanie odrębnych właściwości stylu autora czy w ogóle ludzi” (M, 3-4) oraz wyjaśnienie przyczyn tych różnic.

Czapczyński w swojej Metodyce wyróżnił trzy stanowiska: ujęcie normatywne, strukturalistyczne i idealistyczne.

Stylistyka normatywna kształtowała się pod wpływem światopoglądu pozytywistycznego i ograniczała styl do strony formalnej, a tradycyjną terminologię retoryczną zastąpiła terminologią lingwistyczną. Realizowała dwa cele: dostarczała przepisów poprawnego wysławiania się oraz uczyła, jak formułować sądy estetyczne zgodne $\mathrm{z}$ regułami aktualnego, poddawanego obiektywizacji, gustu literackiego. W praktyce szkolnej — zgodnie z modelem herbartowskim — obowiązywał wyłącznie dedukcyjny tok postępowania, oparty na metodach akroamatycznych, nastawionych na przekaz treści przez prowadzącego zajęcia i ich pamięciowe opanowanie przez ucznia. Edukacja odbywała się według następujących etapów: a) studium teoretyczne, b) czytanie wzorów, c) stosowanie poznanych

${ }^{6}$ T. Czapczyński, Metodyka ćwiczeń stylistycznych w szkole powszechnej i średniej. Podręcznik dla nauczyciela, Lwów 1929 (dalej skrót M i nr strony); tematykę tę poruszał także we wcześniejszych artykułach: idem, Pomocnicze ćwiczenia stylistyczne, „Ruch Pedagogiczny” 1928, nr 1, s. 15-21; nr 2, s. 43-46; $\mathrm{nr} 3$, s. 89-93; idem, Porównania jako materiat do ćwiczeń stylistycznych, „Szkoła i Wiedza” 1927/1928, z. 4, s. 155-166; idem, Przygotowawcze ćwiczenia stylistyczne w zakresie użycia przymiotnika, „Szkoła i Wiedza” 1927/1928, z. 1, s. 9-17.

${ }^{7}$ Termin „stylistyka” pojawił się na początku XIX w.

${ }^{8}$ Pojęcie to ukształtowało się w starożytności na gruncie retoryki i oznaczało ,, charakter wypowiedzi”. 
definicji w praktyce. Powstałe wówczas opisy stylu sprowadzały się do wyliczania środków językowych, podawały typologię rodzajową, normy poprawnościowe, czasami też podejmowały zagadnienia wersyfikacyjne oraz kompozycyjne. Choć zawierały obszerny materiał literacki, nie zamieszczały wskazówek metodycznych, podawały natomiast niewielką liczbę poleceń i pytań adresowanych do uczniów oraz ograniczoną liczbę przykładów i ćwiczeń (podręczniki: Cecylii Boguckiej i Cecylii Niewiadomskiej, Piotra Chmielowskiego, Henryka Gallego, Władysławy Weychert-Szymanowskiej).

Stylistyka strukturalistyczna (Charles Bally, Ferdinand de Saussure ${ }^{9}$ ) kładła nacisk na badanie zjawisk językowych pod kątem ich zawartości uczuciowej. Prowadzone analizy miały charakter funkcjonalny i wiązały się z pojęciem znaku (wartości relacyjnej w tekście) oraz jego miejsca w systemie. Opis struktury języka w perspektywie synchronicznej składał się z uporządkowanych inwentarzy znaków poszczególnych poziomów języka (fonemów, morfemów, form wyrazowych), obejmował określenie zasad ich dystrybucji w tekście oraz funkcje poszczególnych znaków.

Orientacja ta, aplikowana na grunt szkolny, przyniosła zasadnicze zmiany w procesie kształcenia: wyrabianiu estetycznej wrażliwości ucznia służył tok indukcyjny, ukierunkowany na obserwację faktów, konstruowanie hipotez i ich praktyczne weryfikowanie. Młodym ludziom przypadła rola aktywnych uczestników procesu lekcyjnego, zdolnych do formułowania samodzielnych spostrzeżeń i refleksji. W książkach ad usum scholarum (m.in. Lucjusza Komarnickiego i Kazimierza Wóycickiego) pojawił się bogaty literacki materiał egzemplifikacyjny jako źródło różnorodnych ćwiczeń, które miały zainteresować uczniów właściwościami artystycznymi i formalnymi dzieł literackich. W dalszym ciągu autorzy nie uwzględnili jednak komentarza metodycznego.

Stylistyka neoidealistyczna (Benedetto Croce i Karl Vossler ${ }^{10}$ ) nastawiona była na badanie nacechowanych ekspresywnie jednostek języka realizowanych na płaszczyźnie tekstu. Styl pojmowany jako możliwość wyrażania emocjonalności stanowił dopełnienie kodu językowego. Podręczniki szkolne opracowali: Stanisław Szober, Henryk Gaertner i Jakub Sandel.

Innowacyjne projekty Czapczyńskiego dotyczące kształcenia języka ${ }^{11}$ przeciwstawiały się pamięciowemu reprodukowaniu wzorów literackich. Żródeł jego

${ }^{9}$ Por. Stylistyka Bally'ego. Wybór tekstów, przeł. U. Dembska-Prokop, Warszawa 1966; F. de Saussure, Szkice z językoznawstwa ogólnego, przeł., wstęp i red. nauk. M. Danielewiczowa, Warszawa 2004.

${ }^{10}$ Por. B. Croce, Zarys estetyki, Warszawa 1966; K. Vossler, Studia stylistyczne, Warszawa 1972.

${ }^{11}$ Czapczyński pisał o różnicach pomiędzy regionami Polski dotyczących prac nad instrukcjami kształcenia językowego: „w Małopolsce głównie zajmowano się całokształtem programu i zagadnieniami praktycznymi, poszczególnym działom poświęcając stosunkowo mało uwagi, w b. Królestwie, choć nie pomijano spraw ogólnych, które zależnie od stosunków panujących nie mogły mieć takiej, jak w Małopolsce ogólnoobowiązującej wartości i nie mogły jasno i otwarcie 
pomysłów szukać należy we wcześniejszych ruchach reformatorskich w Królestwie Kongresowym (powstanie Związku Nauczycielstwa Polskiego — inicjatora wielu ważnych pism metodycznych ${ }^{12}$ ) i Galicji (na łamach „Muzeum” oraz w latach 1908-1913 w programach nauczania). Część tych postulatów została przeniesiona do praktyki szkolnej XIX w., m.in. w Chowannie Bronisława Trentowskiego $^{13}$ i Wskazówkach do nauki języka polskiego Franciszka Próchnickiego ${ }^{14}$.

Większe zmiany w zakresie kształcenia językowego pojawiły się dopiero w programach po I wojnie światowej, już w wolnej Polsce. Rolę polszczyzny w edukacji podkreślił program ministerialny z 1919 r., nowe treści wnosił Memoriat do Ministerstwa WRiOP w sprawie nauki języka polskiego w szkołach średnich ${ }^{15}$, uchwalony w 1921 r. na zjeździe gramatyków polskich w Krakowie ${ }^{16}$. Wydane dwa lata później Wskazówki metodyczne do programu gimnazjum państwowego. Język polski (gimnazjum wyższe) autorstwa Konstantego Wojciechowskiego, Bogdana Nawroczyńskiego i Stanisława Szobera ${ }^{17}$ były cennym przykładem koherencji materiału teoretycznego i praktycznych umiejętności. Część językowa, opracowana przez ostatniego z wymienionych, to wzorcowy podręcznik dla nauczycieli — z rejestrem treści oraz metodami ich osiągania. Niemniej zaznaczmy, że w ofercie tej nie zawarto zagadnień semantycznych (ograniczono ją do tradycyjnego, opartego na kategorii znaczeniowej, podziału wyrazów na części mowy) ani elementów stylistyki (w dziale „Lektura” pojawiły się adnotacje dotyczące konieczności prowadzenia ćwiczeń synonimicznych, obserwacji stosunków logicznych między pojęciami, analizy porównań oraz badania stylu pisarza na drodze analizy „budowy zdań, słownictwa autora”18).

wypowiadać istotnych celów nauczania języka polskiego, głównie zajęto się prawie nieporuszaną w Małopolsce sprawą zagadnień stylistycznych, a nadto gramatyką i ćwiczeniami piśmiennymi” — cet [T. Czapczyński], [rec.] Język polski (gimnazjum wyższe). Wskazówki metodyczne programu gimnazjum państwowego. Ministerstwo Wyznań Religijnych i Oświecenia Publicznego. Warszawa. Skład główny w Ksiąznicy Polskiej Tow. Naucz. Szkót Wyższych, 1923, str. XI + 588, „Ruch Pedagogiczny" 1924, nr 3-4, s. 83.

12 Zob. Prady w nauczaniu...

${ }^{13}$ B. Trentowski, Chowanna, czyli system pedagogiki narodowej jako umiejętności wychowania, nauki i oświaty, słowem wykształcenia naszej młodzieży, Poznań 1842. Pedagog domagał się całkowitej rezygnacji z reprodukcji materiału lekturowego.

${ }^{14}$ F. Próchnicki, Wskazówki do nauki języka polskiego, Lwów 1885; szerzej na ten temat zob. M. Gajak-Toczek, Franciszek Próchnicki...; eadem, Franciszka Próchnickiego instrukcja programowa i metodyczna, „Acta Universitatis Lodziensis. Folia Litteraria Polonica” 2003, nr 6, s. 469-492.

${ }^{15}$ Memoriat do Ministerstwa WRiOP w sprawie nauki języka polskiego w szkołach średnich, „Język Polski” 1921, nr 2, s. 56-57.

16 Wzięli w nim udział m.in. Jan Łoś, Zenon Klemensiewicz, Kazimierz Nitsch, Jan Rozwadowski, Ignacy Stein, Stanisław Szober.

${ }^{17}$ K. Wojciechowski, S. Szober, B. Nawroczyński, Wskazówki metodyczne do programu gimnazjum państwowego. Język polski (gimnazjum wyższe), Warszawa 1923.

18 Ibidem, s. 188. 
Reforma jędrzejewiczowska zintensyfikowała kształcenie językowe. Ówczesne instrukcje wyodrębniły trzy działy nauczania języka: ćwiczenia stylistyczne wiązano z rozbiorem literackim, a w ramach „Języka” wyróżniono „Naukę o języku” oraz „Ćwiczenia w używaniu języka”; tu zostały ulokowane ćwiczenia w mówieniu oraz pisemne. Wszelkie działania podporządkowano realizacji celów poznawczych (znajomość systemu języka) oraz formalnych (jasne, rzeczowe, poprawne, samodzielne, adekwatne do sytuacji wyrażanie własnych myśli, poglądów i opinii).

\section{Ćwiczenia w mówieniu}

Podręcznik Czapczyńskiego realizował strukturalistyczno-neoidealistyczny model kształcenia. Zawierał propozycje zadań, które miały doskonalić sprawności językowe uczniów w zakresie posługiwania się polszczyzną mówioną. Materiału dostarczały różne źródła: codzienny język młodego człowieka (czynnik środowiskowy) oraz lektura (tu także wypisy ${ }^{19}$ ). Na przekonaniu o fundamentalnym dla rozwoju i życia człowieka znaczeniu kompetencji językowych wzrastały wskazania autora, by wiedzy językowej przyznawać w praktyce polonistycznej służebny charakter. Dostrzeganie potrzeby integracji wewnątrzprzedmiotowej pozwalało w gramatyce widzieć sojusznika ćwiczeń stylistycznych.

Dydaktyczną przydatność tego typu działań Czapczyński widział ponadto w możliwości poznania ucznia: jego światopoglądu, świata ideałów i wartości, motywów dokonywanych wyborów, ,typów wyobraźni” ${ }^{20}$, zamiłowań estetycznych (ĆW, 18). Możliwości i potrzeby zespołu uczniowskiego stały się drugim, obok wskazań programowych, źródłem pojawiającym się w procesie dydaktycznym.

W swym rejestrze ćwiczeń dla niższego poziomu edukacyjnego Czapczyński wyodrębnił różnorodne zadania:

1) Odtwarzanie treści w formie zmienionej, np. opowiadanie w pierwszej osobie zamiast trzeciej, wejście w rolę. Dozwolone było wprowadzanie zmian miejsca, czasu, pory roku. Podstawą wszystkich działań należało czynić „ruch,

19 T. Czapczyński nawiązywał do pozycji: M. Reiter, Czytania polskie (klasy I-III), Lwów 1910-1912; F. Próchnicki, K. Wojciechowski, Wypisy polskie dla szkót średnich (klasy IV-V), Lwów 1911; I. Chrzanowski, K. Wojciechowski, Wypisy polskie dla klas wyższych szkót średnich (klasy VII-VIII), Lwów 1913.

${ }^{20}$ Czapczyński nawiązywał do ustaleń Anieli Szycówny, która wyróżniła następujące typy: a) receptywny - charakteryzuje go myślenie matematyczne, łatwo przyswaja konkretne fakty i b) refleksyjny — skłonny do moralizowania i filozofowania; wydaje samodzielne sądy i tworzy śmiałe przypuszczenia; w obrębie tego typu wskazywała dodatkowo na podtypy: „opisowy (z odmianami: wyliczający, erudycyjny, spostrzegawczy i obrazowy), opowiadający (z odmianami: kronikarski, sprawozdawczy, obrazowy, dramatyczny), refleksyjny obiektywny i subiektywny, i czwarty: uczuciowy" (por. eadem, Metodyka wypracowań, cz. 1. Podstawy psychologiczne i historyczne, Warszawa 1919, s. 34-39. 
zdarzenie, konkretny wypadek" (ĆW, 76), szczególnie w przypadku opisów przyrody, zwyczajów i obyczajów, „w których opisywaniu trzeba koniecznie czynność, współudział ucznia umieć wymyślić i mu narzucié" (ĆW, 76). W pracy nad czytanką O Słowianach (klasa I) Czapczyński sugerował, by młodzi ludzie opowiadali o życiu codziennym członków plemienia i kultywowanych przez nich tradycyjnych zachowaniach; opowieść Pawet $i$ Gawet stanowić mogła z kolei kanwę do przedstawienia zdarzenia $\mathrm{z}$ punktu widzenia bohaterów $\mathrm{i}-\mathrm{w}$ dalszej kolejności — zmiany ról i zarysowania nowych okoliczności (klasa III). Przywołane działania - zaproponowane przez Czapczyńskiego zamiast streszczenia umożliwiały pogłębienie ,znajomości danego ustępu lub utworu, wprowadzając w miejsce mechanicznej powtórki, pierwiastek twórczy i samodzielny" (ĆW, 78). Zbliżały się do technik dramowych: wejście w rolę ułatwiało empatyczne poznawanie odgrywanego bohatera, poszerzało krąg dostępnej rzeczywistości, wiodło do mierzenia się z nieznanymi sytuacjami, wreszcie zachęcało do negocjowania wartości na drodze ich interioryzacji bądź odrzucenia ${ }^{21}$.

2) Uzupełnianie treści przez rozszerzenie lub transformację niektórych szczegółów, dopisywanie początków bądź zakończeń - uwagę należało skoncentrować na logicznym układzie wypowiedzi oraz jej adekwatności faktograficznej i ,psychicznej” do treści czytanki ${ }^{22}$. Omawiając w klasie I czytankę Pod murem więzienia, można było zainspirować gimnazjalistów do twórczego pisania na temat dalszych losów uwięzionego ojca i jego rodziny. Fragment Niewolnik w Rzymie (klasa II) skłaniać miał do ukazania dziejów człowieka przed jego dostaniem się do niewoli.

3) Tworzenie analogicznych do literackich opisów, opowiadań itp. - czytanka stanowiła punkt wyjścia, inspirację i wzór realizacyjny oraz materiał porównawczy. Do grupy tej zaliczył Czapczyński przede wszystkim opisy przyrody (notowanie podobieństw i różnic pomiędzy zjawiskami obserwowanymi

${ }^{21}$ O metodzie tej wiele pisano - por. K. Witerska, Drama: techniki, strategie, scenariusze, Warszawa 2011; E. Ogłoza, E. Polański, E. Szymik, Drama na lekcjach języka polskiego w klasach IV-VIII, Kielce 1997; A. Dziedzic, J. Pichalska, E. Świderska, Drama na lekcjach języka polskiego w szkole średniej, Warszawa 1995; B. Myrdzik, Rola dramy w kształceniu polonistycznym, [w:] Wokót szkoły i nauczyciela: skrypt dla studentów filologii polskiej, red. H. Wiśniewska, J. Plisiecki, Lublin 1995; M. Gajak-Toczek, O budowaniu tożsamości narracyjnej uczniów poprzez działania dramowe na lekcjach języka polskiego w szkole średniej, [w:] Skoro i tak gram ... Edukacja kulturowa poprzez teatr, red. G. Tomaszewska, D. Szczukowski, Gdańsk 2009, s. 159-173; eadem, O metodach aktywizujących (z doświadczenia nauczyciela praktyka), [w:] Problemy poznawania dzieła literackiego w szkole. Tekst, kontekst, znak, znaczenie, red. T. Świętosławska, Łódź 2001, s. 232235; eadem, Propozycje wykorzystania technik dramowych na lekcjach języka polskiego w średnich szkołach zawodowych, Łódź 1994; B. Way, Drama w wychowaniu dzieci i młodzieży, Warszawa 1990; K. Pankowska, Drama - zabawa - myślenie, Warszawa 1990; K. Pankowska, W. Świtała, Drama jako propozycja interpretacji utworów literackich, „Polonistyka” 1989, nr 10, s. 767-773.

22 Czapczyński zaznaczał: „,z]estawienie [...] prób uczniów z oryginałami danych autorów pozwoli im zbadać i określić błędy własnego rozumowania czy fantazji, pogłębi też poczucie pierwiastków kompozycyjnych" (ĆW, 80). 
w określonym przedziale czasu; uwzględnianie zmiany oświetlenia, barw itp.), opisy sprzętów, wyglądu mieszkań, ulic, budynków (początkowo bez terminologii architektonicznej), strojów, obrzędów. Ich celem było doskonalenie umiejętności obserwacji (spostrzegawczość) oraz sprawności w porównywaniu opisów/ ilustracji książkowych z rzeczywistymi obiektami, np. fragment Wilia (klasa I) sugerował zespolić z opowieściami dzieci o rozmaitych zabawach przy choince; czytanka Ottarz Wita Stwosza (klasa III) zachęcała — jego zdaniem — do opisu szczegółów kościołów lokalnych; Lipa inicjować miała relacje z tego, co drzewo widziało; Ukraina i Podole wprowadzała zaś tematykę krajoznawczą.

4) Kreowanie samodzielnych wypowiedzi, dla których tekst literacki stanowił jedynie podnietę, gdyż „uczniowi każe się opierać na sile jego własnych skrzydeł” (ĆW, 84). Ukazywały one bogactwo wyobraźni ucznia - jego zainteresowania ujawniały stosunek do świata, wzrastały bowiem na życiowych spostrzeżeniach i doświadczeniach, np. czytanka Triumf Zawiszy Czarnego stanowić miała punkt wyjścia wypowiedzi na temat Jak się obecnie Polska (Polak) może odznaczyć za granica; ustęp Dobra stużba otwierał drogę ku refleksji o szczęściu.

5) Odtwarzanie przeżyć, wywołanych przez tekst literacki lub powstałych w związku z innymi sytuacjami. Istotne było motywowanie wychowanków do szczerości. Po omówieniu czytanki $W$ karaibskim wąwozie (klasa I) należało podjąć rozmowę o codziennych obowiązkach młodych ludzi i ich relacjach z kolegami i koleżankami, nauczycielami i rodzicami. Fragment $O$ cudzie (klasa II) służył namysłowi nad znaczeniem miłości w świecie.

W starszych klasach Czapczyński proponował improwizowane lub wcześniej przygotowane (w tym przypadku oczekiwał estetycznego wygłoszenia, a nie odczytania przygotowanych wystąpień) różnorodne ustne formy wypowiedzi, m.in. referaty czy mowy ${ }^{23}$ na aktualnie ważne tematy. „W każdym ćwiczeniu historycznoliterackim musi się uwzględniać — pisał Czapczyński — moment twórczy, dający pole do samodzielności, a budzący w ten naturalny sposób zainteresowanie" (ĆW, 97). Umożliwiały one prezentację problematyki:

a) syntetycznie, np. dygresje w Beniowskim łódzki polonista sugerował łączyć z biografią poety: Życie wewnętrzne Stowackiego, Stosunek krytyków do Stowackiego, Stosunek Stowackiego do religii;

b) poprzez tworzenie paralel literackich (np. Zestawienie Judyma z Kordianem, Rozluckiego z Konradem, ludowości Brodzińskiego z ludowościa Konopnickiej czy Kasprowicza ${ }^{24}$ ); na tej płaszczyźnie radził eksponować najskrytsze doznania psychiczne, przeżycia zarówno bohaterów, jak i uczniów, np. interpretując Dziadów część IV Mickiewicza, gimnazjaliści mogli porównać odczucia Gustawa z własnymi;

${ }^{23}$ Rangę tym ćwiczeniom nadał dopiero Program nauki w gimnazjach, Warszawa 1934.

${ }^{24}$ Ibidem. 
c) „retrospektywnie”, z uwzględnieniem całości problematyki (np. Sielanka jako odbicie pradów literackich w poszczególnych epokach; Stosunek do Boga, człowieka, natury w literaturze różnych epok);

d) w odniesieniu do myśli krytycznej i naukowych komentarzy w celu ,zaznajomienia ze stanem wiedzy, uzupełnienia zakresu lekcji, podania nowych bodźców zarodczych dla badawczej myśli ucznia, [...] pobudzenia inwencji” (M, 100), twórczego odwoływania się do refleksji innych, umiejętnego argumentowania;

e) komparatystycznie, np. podczas analizowania i interpretowania Ody do młodości Mickiewicza należało wyeksponować kwestie związane z sytuacją polityczną w Europie na przełomie XIX i XX w., utratą przez Polskę niepodległości, przyczynami walki klasyków z romantykami, wynikającymi z odrębnych programów estetycznych, różnych hierarchii wartości i wyznawanych ideałów, odmiennego pojmowania zadań społecznych;

f) z uwzględnieniem zasady aktualizacji treści - Powrót posła Niemcewicza stwarzał sposobność do refleksji o roli polityki w życiu społeczeństwa (obraz polityka realizującego ideały antycznej virtus), sposobach służenia krajowi na początku XX w. (maksyma „dom zawsze ustępować powinien krajowi”), celach nauki języków ojczystego i obcych oraz historii;

g) w odniesieniu do erotyki człowieka — powinno się zachęcać młodzież do szczerości, unikać niepotrzebnego patosu; podkreślać należało „wartości życia rodzinnego, korzyści z niego płynące, piękno, jakie w nim tkwi, źródło podniosłych uczuć, wreszcie obowiązki względem ojczyzny" (ĆW, 107); Czapczyński wskazywał, by omawianiu nieporozumień między Henrykiem a Marią w Nie-Boskiej komedii Krasińskiego towarzyszył namysł nad warunkami niezbędnymi do tworzenia udanych związków i nad społeczną doniosłością małżeństwa; w odniesieniu do IV części Dziadów rekomendował dyskusję o „,echach zdrowej miłości”; dostrzegał również wychowawcze korzyści płynące z porównania sposobów mówienia o miłości w wierszach erotycznych Kochanowskiego, Kochowskiego, Morsztyna;

h) z nastawieniem na prezentację uczuć związanych z religią, płciowością człowieka, poglądami społeczno-politycznymi, stosunkiem do innych osób, lekturą; warunkiem ich prowadzenia było wzajemne zaufanie między partnerami procesu nauczania; wśród tematów przykładowych Czapczyński umieścił m.in.: Noc księżycowa (myśli, uczucia, pragnienia) na podstawie IV części Dziadów Mickiewicza; Jak na mnie oddziaływają: deszcz, góry, las? (w odniesieniu do Sonetów krymskich wieszcza); podczas omawiania Kordiana sugerował porównanie świata emocji bohatera widocznych w monologu z przeżyciami ucznia;

i) z wykorzystaniem mów okolicznościowych (rocznice, święta narodowe), odnoszących się do życia szkolnego oraz lektur (ocena postępowania Konrada Wallenroda, Balladyny, Henryka bądź Pankracego z Nie-Boskiej komedii); wygłaszane miały być nie z ławki, lecz z katedry, ,aby uczeń przyzwyczaił się do widoku słuchaczy i nauczył się liczyć z warunkami oddziaływania mówcy na słuchaczy i na odwrót" (M, 114). 
Powstałe wypowiedzi miały spełniać zasady logiki, ,wyboru i uczciwości dowodów, porządku, podziału" 25 , zawierać prawdziwe myśli, ujęte w stosownej szacie językowej. Były skutecznym środkiem zapobiegającym werbalizmowi. Mobilizowały wychowanków do intencjonalnego posługiwania się zasobem środków językowych w zależności od przekazywanych treści, przyjmowanej formy, nastawienia emocjonalnego i sytuacji mówienia ${ }^{26}$. Podczas ich wykonywania należało zwracać uwagę na estetykę mówienia, odpowiednie frazowanie, intonację, stawianie akcentów logicznych, tempo, artykulację, barwę dźwiękową ${ }^{27}$.

Warto dodać, że o nowatorstwie propozycji zgłoszonej przez autora podręcznika świadczy fakt, że dopiero w programach zreformowanych po 1932 r. ,,pozwolono uczniom mówić" 28 . Porządek: mówienie - czytanie — pisanie w klasach I-III zmieniono od klasy IV na: czytanie - mówienie — pisanie. Program nauki w publicznych szkołach powszechnych z 1934 r. wprowadzał dwa nowe działy: „Tematy ćwiczeń w mówieniu, czytaniu i pisaniu” oraz „W związku z mówieniem, pisaniem i czytaniem" 29 . Ważnym krokiem w podnoszeniu rangi ćwiczeń w mówieniu był Program nauki w gimnazjach $\mathrm{z}$ tego samego roku, w którym położono nacisk na konieczność kształtowania sprawności językowej; koncentrował on uwagę na „samych czynnościach mówienia i pisania”, pozbawiając je jedynie funkcji kontrolnej. W instrukcji z $1937 \mathrm{r}$. w gimnazjum dwuletnim uwypuklono konieczność budowania wystąpień argumentacyjnych na podstawie materiałów wieloźródłowych oraz dyskusję.

\section{Metodyka ćwiczeń stylistycznych}

Założenia konstrukcyjne i metodologiczne Metodyki ćwiczeń stylistycznych w szkole powszechnej i średniej Czapczyński przedstawił w uwagach wstępnych, notując:

25 Ibidem, s. 114.

26 J. Biliński zaprezentował ćwiczenia rozwijające ,zdolność obserwacji” i ,wyrażania sprawności słownej" według metody tzw. planu daltońskiego - idem, Ćwiczenia słownikowe w związku z wypracowaniami, Poznań 1931, s. 116-124. L. Skoczylas, ubolewając nad niedostatecznie rozwiniętą u uczniów zdolnością do samodzielnego myślenia, choć upominał się już w $1914 \mathrm{r}$. o ćwiczenia rozwijające wyobraźnię, to jednak nie akceptował np. parafrazy tekstu czy indywidualnego uzupełnienia - idem, Lektura powieści w szkole średniej, [w:] Sprawozdanie Dyrekcji c.k. Gimnazjum im. Franciszka Józefa we Lwowie za rok szkolny 1914, Lwów 1914, s. 27-32; idem, Referat Krakowskiej Sekcji Polonistów w sprawie nauczania języka polskiego w wyższych klasach szkoły średniej, [w:] Pamiętnik II Ogólnopolskiego Zjazdu Polonistów w Krakowie, Warszawa-Lwów 1931, s. 48-58.

27 Badacz zalecał stosowanie zasad wyłożonych przez J. Tennera, Estetyka żywego słowa, Warszawa 1904; idem, Technika żywego słowa, Lwów-Warszawa 1906.

28 Por. M. Nagajowa, Ćwiczenia w mówieniu i pisaniu w klasach IV-VIII szkoły podstawowej, Warszawa 1977.

${ }^{29}$ Por. Program nauki w publicznych szkołach powszechnych trzeciego stopnia z polskim językiem nauczania (tymczasowy), Lwów 1934, s. 247-283.

Kształcenie Językowe 16 (26), 2018

(C) for this edition by CNS 
Praca niniejsza nie ma na celu stworzenia jakiegoś szablonu, schematu, jest ona tylko próbą rozwiązania jednego z zagadnień metodycznych i pragnie nauczycielstwu ułatwić osiągnięcie celów, wytkniętych przez programy nauczania języka polskiego. Przedmiotem jej są ćwiczenia stylistyczne, nie w znaczeniu ćwiczeń piśmiennych, ale w znaczeniu przygodnie, choć systematycznie badanych zjawisk językowych, objętych nazwą stylistyki. Zajmuje się ona ćwiczeniami stylistycznymi w oddziale IV, V, VI i VII szkoły powszechnej, względnie w klasach I, II, III, a po części IV i V szkoły średniej ogólnokształcącej (M, 1).

Podkreślał również, że wcześniej powstałe podręczniki do nauczania stylistyki pióra Komarnickiego i Wóycickiego „bezpośrednie zastosowanie znaleźć mogą dopiero w klasach wyższych, w klasach zaś niższych przez swój wysoki poziom [...] mogą wywołać pewne nieporozumienia i wprost przeciwne zamierzeniom autorów skutki” $(\mathrm{M}, 1)$.

Przystępując do pracy nad utworem literackim, nauczyciel powinien go przeczytać z uczniami, a następnie wykonać szereg działań. Pierwszy etap stanowiły pomocnicze ćwiczenia stylistyczne:

1) Podawanie wyjaśnień rzeczowych poprzez tworzenie definicji, wyszukiwanie synonimów. Pedagog przestrzegał jednak przed zbyt drobiazgowym omawianiem pojęć czy zjawisk. Stwierdzał, iż należało wprowadzać informacje konieczne i łączyć je z wiedzą już posiadaną przez wychowanków. Zalecał także, by młodzi ludzie pracowali ze słownikami.

2) Ćwiczenia słownikowe i logiczne, wykonywane po powtórnym odczytaniu tekstu, obejmujące: a) tworzenie szeregów synonimicznych do wyrazów z czytanki; b) uzupełnianie szeregów synonimicznych z wypowiedzi wychowanka; c) gromadzenie szeregów synonimicznych do danego wyrazu; d) wyszukiwanie homonimów lub antonimów. Według Czapczyńskiego wymagały one znacznej samodzielności młodzieży, a ich celem było „wzbogacenie słownictwa i wyjaśnienie pojęć, względnie utrwalenie ich i wysubtelnianie. Pod względem metodycznego charakteru najbardziej zbliżały się one do ćwiczeń gramatycznych" $(\mathrm{M}, 1)$. Autor Metodyki apelował, by obserwacja języka obejmowała nie tylko pojedyncze wyrazy, lecz całe zdania. Wspomnieć wypada, że — w jego przekonaniu — tego rodzaju zadania wywoływały żywe zainteresowanie młodzieży, zmuszały do dyskusji, ścisłego badania materiału językowego, „nadając pracy twórczą radość zdobywania, o ile jednak nie traktowało się ich zbyt szablonowo" (M, 27). Zwrot w stronę korelatów emocjonalnych literatury spowodował, że kształcenie wrażliwości na dzieło sztuki stało się jednym z głównych celów nauczania języka polskiego w szkole.

Drugi etap pracy nad utworem obejmował:

1) Badanie synonimów, przenośni, porównań itd. w związku z treścią danego utworu, czytanki czy opowiadania ucznia ze względu na wartości: myślowe, uczuciowe i malarskie z uwzględnieniem semantycznego aspektu poszczególnych części mowy. 
2) Twórcze rozpoznawanie związku elementów stylistycznych z treścią przez opuszczanie wyrazów, przenośni, porównań i zastępowanie ich innymi ${ }^{30}$. W przekonaniu dydaktyka, postępowanie takie służyło z jednej strony bogaceniu słownictwa, z drugiej zaś uwrażliwiało na rolę słowa w wypowiedzi, ucząc odpowiedzialnego posługiwania się językiem.

3) Charakteryzowanie utworu jako całości stylistycznej. Praca ta pozwalała uczniom uświadomić sobie, że poszczególne słowa wiązały się w sensy, które wynikały z traktowania tekstu jako całokształtu komplementarnych względem siebie elementów, różnorodnych zabiegów artystycznych, technik prezentowania świata, sposobów literackiej kreacji stosowanych świadomie przez autora w celu uzyskania zamierzonych efektów. Nie dziwi zatem, że podczas analizy lektury pedagog proponował przede wszystkim badanie jej struktury, przekonywał, że trzeba odkryć w utworze zasadę porządkującą, która funkcjonalnie organizowałaby treści w celu spełnienia jego funkcji estetycznej. W związku z tym należało uwzględnić: dźwiękową stronę języka, jego stronę znaczeniową (uchwycenie ,zbioru środków charakteryzujących dzieło jako całość znaczeniową", a więc jego kompozycję) i dziedzinę tematyczną (elementy stałe: podmiot autorski, jego stosunek do tematu, sposób przedstawienia; czas; obraz świata zewnętrznego; strategia kreowania świata realnego, zobrazowanie kręgów społecznych, ideologia). Opis elementów umożliwiał stwierdzenie, jakie zabiegi artystyczne były dla danej pozycji decydujące, a także wskazanie stosunku materiału językowego i tematycznego do zabiegów artystycznych, jak też uwypuklenie czynników podporządkowujących sobie składniki pozostałe. Nie chodziło przy tym tylko o spis wszystkich zjawisk, ale o zrozumienie ich funkcjonalności. Projektowana przez badacza funkcjonalna analiza utworu (metoda pośrednia ${ }^{31}$ ) uzależniona była od właściwego określenia jego dominanty czy jak chciał Konstanty Wojciechowski — jego „swoistej fizjognomii”32. Czapczyński zdawał sobie sprawę, że często główna konstytuanta dzieła nie leżała w jego ,treści”, lecz właśnie w „formie”, w jego stylu, kompozycji, wersyfikacji.

4) Określanie roli części mowy lub różnorodnych elementów stylistycznych w opowiadaniu wychowanka; ten element umożliwiał — w opinii badacza kształtowanie w młodych ludziach umiejętności samodzielnego, świadomego i funkcjonalnego konstruowania własnych wypowiedzi adekwatnie do potrzeb, odczuć i okoliczności.

Trzecim etapem pracy analityczno-interpretacyjnej były ćwiczenia pokrewne:

1) Nadawanie tytułów czytankom niezatytułowanym, poszczególnym częściom, obrazom lub cyklom obrazków oraz opowieściom młodego człowieka.

30 Zob. również: T. Czapczyński, Porównania jako materiat..., s. 158.

${ }^{31}$ Czapczyński wyróżnił jeszcze metodę bezpośrednią — określenie głównego przesłania utworu za pomocą pytań nauczyciela po stosownych objaśnieniach rzeczowych. Kolejnymi etapami pracy było pogłębianie zagadnienia poprzez ćwiczenia w mówieniu (scenki, dialogi, parafrazy) lub/i pisanie wypracowań.

${ }^{32}$ K. Wojciechowski, S. Szober, B. Nawroczyński, op. cit., s. 94. 
Zabieg - w zamierzeniu pedagoga - miał na celu ,wynalezienie najodpowiedniejszego wyrazu, odpowiadającego danej treści. Dojście do tego wyrazu mogło nastapić albo intuicyjnie, albo drogą analizy treści czytanki czy obrazu" (M, 125). Zadania takie wymagały „ruchu myśli” i głębokiego „cieniowania uczuć" (M, 125).

2) Opisywanie przedmiotów, czynności, obrazków, rzeźb itp. Prace te inspirowały wychowanków do uważnego i rzetelnego zapoznania się z treścią analizowanych tekstów w celu znalezienia określeń, które w syntetycznym ujęciu oddawałyby ich zasadnicze przesłanie. Tytuły poszczególnych części winny się „Zmieścić w nadrzędnym tytule, obejmującym całość” (M, 125).

3) Opowiadanie „Z użyciem danych elementów stylistycznych” (M, 125). Czapczyński inspirował pedagogów do proponowania tematów twórczych, które stwarzałyby możliwości do świadomego dobierania środków językowych, np. temat Wesoła wycieczka ,każe uczniowi nie tylko dać treść wesołą, ale też uczy całego szeregu np. przymiotników, które będą tę wesołość podkreślały, albo też komicznych porównań" (M, 125). Zachęcając do podejmowania działań kreatywnych, badacz zaznaczał: „Ćwiczeń tych nie należy traktować szablonowo, ale [...] należy dbać o wypowiadanie się indywidualne, oryginalne, samodzielne i twórcze" (M, 125). Wskazówek metodycznych mogli nauczyciele szukać m.in. w Ćwiczeniach słownikowych w szkole powszechnej ${ }^{33}$ Gaertnera oraz Przewodniku metodycznym do „Czytanek polskich”34 Stanisława Tynca, Józefa Gołąbka.

Czapczyński zaprezentował w Metodyce bogaty i inspirujący materiał egzemplifikacyjny. Pracę nad rzeczownikiem zilustrował na przykładzie Wilczka Ignacego Krasickiego. Na początku uczniowie poprzez tworzenie synonimów mieli wyjaśnić znaczenie słów: wilk, manowce, skruput, jama. Następnie określali rodzaj rzeczowników, funkcje archaizmów (jegomość, jejmość) oraz wyrazów zdrobniałych (wilczek, kurczę, kogutek); ich zestawienie w pary z innymi, np. wilczek — wilk, kurcze — kura, kogutek — kogut, ułatwiało wniknięcie w ,istotę bajki i w jej humor i dowcip" (M, 44).

Przymiotnik $^{35}$ - w przekonaniu łódzkiego polonisty - wprowadzał do ćwiczeń stylistycznych urozmaicenie, albowiem określając właściwości przed-

${ }^{33}$ H. Gaertner, Ćwiczenia słownikowe w szkole powszechnej, Lwów 1927.

${ }^{34}$ S. Tync, J. Gołąbek, Przewodnik metodyczny do „, Czytanek polskich” dla klas I, II gimnazjum, Lwów-Warszawa 1927-1928; eidem, Przewodnik metodyczny do „Czytanek polskich” dla IV oddziału szkoły powszechnej, Lwów 1928; później ukazały się jeszcze: eidem, Poradnik metodyczny do „Czytanek polskich” dla IV klasy szkót powszechnych pierwszego stopnia. Kurs A, Lwów-Warszawa 1936; eidem, Przewodnik metodyczny do „Czytanek polskich” dla IV klasy szkót powszechnych pierwszego stopnia. Kurs B, Lwów-Warszawa 1938.

35 Posługiwanie się odpowiednimi formami przymiotnika — pisał Czapczyński — ,jest wynikiem indywidualnej reakcji jednostki i jej rozwoju uczuciowego". Ćwiczenie ukierunkowane na stosowne do treści posługiwanie się formami przymiotnikowymi „przyczyniają się ogromnie do rozwoju psychicznego młodzieży, podnoszą ją niejako na wyższy stopień poznania" — idem, Przygotowawcze ćwiczenia stylistyczne..., s. 9. 
miotów, wyrażane przez rzeczownik, nie tylko wyjaśniał, rozszerzał i uwypuklał przedmiot, lecz nadto zabarwiał go zależnie od naszego subiektywnego stanu pod względem uczuciowym, etycznym, malarskim, pozwalając na zaznaczanie „najsubtelniejszych różnic" semantycznych. Analiza wyrazów wiodła do ich wartościowania (pytanie rzeczownika: „co to jest?” uzupełnione zostało wnikliwym przymiotnikowym: ,jakie to jest?”). Sposób dydaktycznego postępowania Czapczyński przybliżył, m.in. omawiając Dziewczynkę z zapałkami (klasa I). Sugerował wyodrębnienie ciągów synonimicznych: a) rzeczowników bezpośrednio charakteryzujących bohaterkę (dziewczynka, dziewczatko, mała, dziewczę, sierotka, maleństwo, biedactwo, wnuczka), b) rzeczowników opisujących postać w sposób pośredni (fartuszek, płatki, gwiazdki, kacik, pudeteczko, babka, babunia, twarzyczka, izdebka, drewienko, płomyk, nóżki itd.), c) wskazanie znaczenia przymiotników (mała, biedna, onieśmielona, drżaca, zgłodniała, zmęczona, drobne biedactwo, różowa twarzyczka), d) wyróżnienie określeń odnoszących się do różnych przestrzeni i doznań, np. domu, słyszanych dźwięków, płomienia [przedziwny płomyk, jasny błysk, odblask, świeczki, blask, światełka, szerokie kręgi jasności, przestworza świetlne, promień, jasne słońce, brzask, powłóczysta smuga (światta), snopy światta, srebrzyste gwiazdki]. Te ostatnie uwypuklały chociażby kontrast pomiędzy realną rzeczywistością a światem marzeń dziecka. Wszystkie natomiast mówiły o jego tragicznych losach w wieczór sylwestrowy, ostatni nie tylko w roku, ale i w życiu bohaterki. Przymiotniki odnosiły się również do otoczenia, w którym się ona znalazła: obcych, nielitościwych ludzi. Bogaceniu słownictwa służyły tworzone na lekcji ciągi synonimiczne, a także odpowiedni dobór przymiotników, pozwalający na precyzyjniejsze nazywanie sytuacji (np. dom, poddasze, izdebka, izba; szum, poświst, trzask; dobroczynny, dobry, dobrotliwy, serdeczny; wielki, wspaniaty, bogaty, niezrównany, wytworny, duży). Dodatkowo nauczyciel mógł zaproponować tworzenie synonimów do rzeczowników odnoszących się np. do stanów psychicznych człowieka w życiu codziennym, a następnie wzbogacanie ich znaczeń przez treści zawarte w przymiotnikach.

Podpowiadając metodyczne rozwiązania związane z czasownikiem (wielość form koniugacyjnych i trybów, strona czynna i bierna, przechodnie i nieprzechodnie), Czapczyński przywołał m.in. czytankę Lokatorowie choiny, opowiadającą o losach wiewiórki. Zestawienie ciągów synonimicznych: wyszła, wyleciała, przebiegła; skoczyła, porwała się, wróciła; zbiegła, wgramoliła się, skłoniła; przebiegła, przykucnęta, wdrapała się; zabiegła, przyskoczyła, odskoczyła; szła; wpadła ułatwiało odtworzenie akcji ,z wszystkimi jej upadkami i wzniesieniami”, jak też scharakteryzowanie bohaterki. Autor Metodyki proponował także zwrócenie uwagi na semantyczną i stylistyczną wartość czasowników dokonanych i niedokonanych, imiesłowów, przedrostków i przyrostków. W podobny sposób można było opisywać pozostałe postaci opowiadania.

W pracy nad utworem literackim należało uwzględniać wartość znaczeniową przysłówka. Materiałem egzemplifikacyjnym uczynił Czapczyński czytankę 
Gniazdo bocianie, w której ta część mowy określała relacje czasowe (później, naprzód) oraz ułatwiała charakteryzowanie występujących osób (np. formy na przemian, kolejno uwypuklały umiejętności współpracy; szybko, powoli mówiły o sposobach reakcji).

Czapczyński wskazywał również na konieczność podjęcia refleksji nad istotą tropów stylistycznych, po które sięgali artyści ${ }^{36}$. Za szczególnie bliskie młodym ludziom uznał porównania ${ }^{37}$, sugerując, by skala ćwiczeń w tym zakresie była „ogromnie bogata” (M, 80) (przywołał przykłady zaczerpnięte z Iliady Homera, Wiesława Kazimierza Brodzińskiego, Ojca zadżumionych Słowackiego, Pana Tadeusza Mickiewicza). Pedagog analizą objął: a) spójniki porównawcze, b) porównania jedno- i dwuczłonowe, c) porównania pojedyncze i złożone, d) tertium comparationis (co z czym porównujemy, jakie dziedziny życia łączymy lub przeciwstawiamy), e) pełnioną rolę (np. uwzględnienie tego, czy charakteryzują osoby, rzeczy, cechy, działania, stany, czy zatrzymują akcję lub wprowadzają retrospektywne ujęcia, czy też stanowią element wiążący poszczególne wydarzenia w zwartą całość), f) miejsce, w jakich się pojawiają (np. opis, opowiadanie, rozmowa), g) stopień skonwencjonalizowania użycia, h) sposób współistnienia z innymi elementami utworu, i) właściwości mówiącego, otoczenia, słuchacza, autora.

Analogicznie należało wyjaśniać sensy innych środków artystycznych.

Czapczyński, dostrzegając potrzebę łączenia literaturoznawstwa $\mathrm{z}$ wiedzą językoznawczą, był przekonany, że kluczem otwierającym rzeczywistość tekstu była analiza językowa, a procedura opisowo-interpretacyjna stylistyki powinna zająć centralne miejsce w badaniach nad dziełem (funkcjonalność poznanych

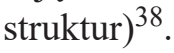

Zaznaczmy, że ułożony przez Czapczyńskiego plan ćwiczeń mógł być realizowany na różnych szczeblach edukacji polonistycznej. Autor podręcznika dla nauczycieli

wyrabiał poprawność języka, a nadto z wolna wprowadzał w tajemnicę piękna, w odczuwanie dzieł sztuki przez rozwinięcie (obok ścisłości w używaniu języka) fantazji i poczucia piękna w skromnym wprawdzie zakresie, ale wystarczającym na tym poziomie nauczania (M, 18-19).

W przedstawionej propozycji, zespalając nurt normatywny, estetyczno-psychologiczny i lingwistyczno-emocjonalny, kładł nacisk na wartości emocjonalne i artystyczne stylu, nie pomijając aspektu logicznego; nadto dotychczasowemu katalogowaniu figur i uczeniu się ich użycia przeciwstawił próbę rozpoznawania ich sensu i skuteczności.

36 Niewiele miejsca poświęcił metaforze, gdyż wcześniej zajmowano się nią w rozmaitych opracowaniach metodycznych.

37 Przed Czapczyńskim najobszerniej istotę porównań wyjaśniał L. Komarnicki, Stylistyka polska, Warszawa 1922, s. 186.

$38 \mathrm{~W}$ swoich publikacjach konsekwentnie upominał się o zespalanie w analizie i interpretacji zagadnień treści i formy. 
Idea funkcjonalnego nauczania polszczyzny umożliwiła Czapczyńskiemu traktowanie języka jako zjawiska semiotycznego, a literatury jako wzorca zachowań językowych (pojęcie znaku, podstawowe funkcje znaku językowego: komunikowanie, informowanie, ekspresja, impresja). Była też sposobem łączenia nauczania struktur gramatycznych (budowa języka) z ćwiczeniami służącymi bogaceniu zasobu słownikowego i frazeologicznego ucznia. Celem działań polonisty miało być tworzenie przez wychowanków wypowiedzeń ustnych i pisemnych, charakteryzujących się leksykalną i składniową spójnością. Ze wszech miar słuszne, także i w świetle ustaleń współczesnych badaczy, było umieszczenie w centrum praktyki edukacyjnej ćwiczeń wspierających umiejętności komunikacyjne (nadawcze i odbiorcze). Źródeł inspiracji zaprezentowanych tu zapatrywań Czapczyńskiego na proces odbioru dzieła literackiego jako swoistego komunikatu szukać można w zaproponowanej przez Wilhelma Diltheya koncepcji „rozumienia wyższego", utożsamianego z wynikaniem, którego istotą było „transponowanie [Übertragung] własnej jaźni na dany zespół ekspresji życia" ${ }^{39}$ naśladowaniem oraz przeżywaniem odtwórczym.

Zważywszy, że w zasadzie właściwą rangę ćwiczeniom w mówieniu i pisaniu nadały w Polsce dopiero programy po reformie jędrzejowiczowskiej, inspirowane poglądami niemieckich pedagogów Georga Kerschensteinera i Hugona Gaudiga, propozycje autora Metodyki są zaskakująco zróżnicowane i bogate.

\section{Podsumowanie}

Konkludując, warto stwierdzić, że o randze osiągnięć Czapczyńskiego świadczy otwartość na wyzwania szkolnej empirii. Młodego człowieka pedagog uczynił centralnym punktem procesu kształcenia, dostrzegał bowiem pojawienie się w dyskursie filozoficzno-edukacyjnym na początku XX w. nowego obrazu podmiotu - jednostki twórczo przekształcającej otaczającą rzeczywistość, by tworzyć swoją tożsamość poprzez uczestnictwo w lokalnym środowisku społecznym i kulturowym, przyjmowanie jego wzorów myślenia, zachowania, jego tradycji i historii. Konsekwentnie podkreślał, że poznawcze treści nauczania powinny wspierać realizację celów wyższych kategorii, a mianowicie formować postawy i umiejętności, budzić szacunek dla uniwersalnych wartości, których interioryzacja stanowi finalne i priorytetowe zadania szkoły. Wiadomości nabywane na lekcjach nie mogły zatem mieć charakteru odtwórczego, nie o terminy, definicje, prawa, normy i zasady chodziło, ale o wiedzę w ruchu, kreatywnie wykorzystywane narzędzia myślenia, działania, odczuwania. Powiązanie kształcenia polonistycznego z życiem ucznia było istotnym czynnikiem, zwiększającym jego efektywność. Sprawne posługiwanie się polszczyzną jako środkiem do pozna-

${ }^{39}$ W. Dilthey, Rozumienie, przeł. K. Krzemieniowa, [w:] Z. Kuderowicz, Dilthey, Warszawa 1987, s. 214-233. 
wania i nazywania świata służyło kształtowaniu „Ja” wychowanka. Dialogiczne nastawienie partnerów edukacji: nauczyciela i ucznia umożliwiało kreowanie podmiotowości cechujących się postawami otwartości na Drugiego. Dydaktyka szkolna, zdaniem tego nauczyciela praktyka, miała wspierać młodzież w budowaniu autentycznej i spójnej tożsamości, nie zaniedbując przy tym „ćwiczenia się” we wrażliwości na odmienność.

Tendencje reformatorskie, ukierunkowane na wychowanie człowieka zdolnego do sprostania wyzwaniom jutra, wypełniają również przestrzeń edukacyjną pierwszych dwóch dekad XXI w. Współczesne założenia programowe są zbieżne z tymi, które przyświecały pedagogom, w tym Czapczyńskiemu, u progu ubiegłego stulecia. Ćwiczenia w mówieniu i ćwiczenia stylistyczne stanowią oś działań polonistycznych, ukierunkowanych na całościowy rozwój człowieka. Ich celem jest przygotowanie wychowanka do podejmowania twórczych i odpowiedzialnych działań językowych. Kompetencja komunikacyjna rozumiana jest jako teoretyczna i praktyczna gotowość oraz zdatność do pełnienia ról nadawcy i odbiorcy różnorodnych treściowo, formalnie i komunikacyjnie komunikatów, transmitowanych i przyjmowanych w różnych sytuacjach, determinowanych typem kontaktu pomiędzy partnerami, stosunkiem, okolicznościami zewnętrznymi (a) przedstawianie, opisywanie stanu rzeczy i przedmiotów, b) wyrażanie siebie, c) oddziaływanie na innych). Za ważne uznaje się rozwijanie wiedzy o elementach składowych wypowiedzi ustnych i pisemnych oraz ich funkcjach w strukturze tekstów i w komunikowaniu, wyrobienie świadomości dotyczącej złożoności systemu języka (znajomość różnorodnych pojęć i terminów). Idea zintegrowanego kształcenia językowo-przedmiotowego nie utraciła na swej aktualności. Rozwijanie językowych kompetencji przez działanie dynamizuje proces edukacyjny, ułatwia przyswajanie i zapamiętywanie treści. Szkoła korzysta z ustaleń pragmalingwistyki (John Austin, John Searle; ważne są akty nadawczo-odbiorcze i realizowane przez funkcje wypowiedzi), socjolingwistyki (za punkt wyjścia przyjmuje społeczne istnienie języka i dąży do ujawnienia socjologicznie uwarunkowanych właściwości języka), lingwistyki tekstu (bada tekst jako całościowo zorganizowany komunikat językowy) oraz kognitywizmu (założenie, że język jest ściśle powiązany z umysłowymi procesami dotyczącymi poznawania świata). Dziś - podobnie jak czynił to Czapczyński — kładzie się nacisk na funkcjonalny aspekt kształcenia. Językoznawcy (Kordian Bakuła, Jerzy Bartmiński, Edyta Bańkowska, Teresa Dobrzańska, Jadwiga Kowalikowa, Jadwiga Puzynina, Helena Synowiec, Halina i Tadeusz Zgółkowie, Urszula Żydek-Bednarczuk) zalecają sytuowanie ucznia w roli badacza i odkrywcy faktów, nauczycielowi przypisując rolę przewodnika na drodze zdobywania wiedzy. Obok przekazywania wiedzy o strukturze języka i jego funkcjach postulują zwrócenie uwagi na umiejętności zgodne z normą poprawnościową i postawy oparte na wartościowaniu estetycznym i etycznym, podkreślają, że cele poznawcze podporządkowane powinny być doskonaleniu języka, a kształcenie językowe integrowane z literackim. Naucza- 
nie funkcjonalne przyjmuje, że w kształceniu językowym najistotniejszy jest cel kształcący, realizowany przede wszystkim poprzez zajęcia praktyczne. Jego idee realizuje cykl podręczników To lubię! Barbary Dyduchowej, Marii Jędrychowskiej, Zofii Agnieszki Kłakówny, Haliny Mrazek, Iwony Steczko.

Edukacji jako procesowi ciągłemu, nieustannie zmieniającemu się, patronują ideały przeszłości, wydaje się więc, że warto pamiętać o wypracowanych wcześniej koncepcjach, by planując nowe, osadzać działania w odpowiednim kontekście. Refleksja poprzedników z pewnością pozwoli na uniknięcie wielu błędów, a także stać się może źródłem inspiracji dla podejmowanych inicjatyw.

\section{Bibliografia}

Baudouin de Courtenay J., Znaczenie języka jako przedmiotu nauki szkolnej, [w:] Prądy w nauczaniu języka ojczystego, [praca zbiorowa], Warszawa 1908, s. 1-12.

Biliński J., Ćwiczenia słownikowe w zwiazku z wypracowaniami, Poznań 1931.

Bogołębska B., Czapczyński Tadeusz (1884-1958), [w:] Słownik badaczy literatury polskiej, red. J. Starnawski, Łódź 1994, s. 55-61.

cet [T. Czapczyński], [rec.] Język polski (gimnazjum wyższe). Wskazówki metodyczne programu gimnazjum państwowego. Ministerstwo Wyznań Religijnych i Oświecenia Publicznego. Warszawa. Skład główny w Książnicy Polskiej Tow. Naucz. Szkót Wyższych, 1923, str. XI + 588, „Ruch Pedagogiczny” 1924, nr 3-4, s. 83-89.

Chrzanowski I., Wojciechowski K., Wypisy polskie dla klas wyższych szkót średnich (klasy VII-VIII), Lwów 1913.

Croce B., Zarys estetyki, Warszawa 1966.

Czachowska J., Czapczyński Tadeusz, [w:] Współcześni polscy pisarze i badacze literatury. Stownik biobibliograficzny, oprac. J. Czachowska, A. Szałagan, t. 2, Warszawa 1994, s. 80-82.

Czapczyński T., Aleksander Fredro, Łódź 1947.

Czapczyński T., Ćwiczenia w mówieniu. Przyczynek do metodyki języka polskiego, Warszawa 1922.

Czapczyński T., Hugo Kollątaj, Warszawa 1948.

Czapczyński T., Idzie sobie bobas mały, Łódź 1948.

Czapczyński T., Ksiązeczka trochę nowa, trochę stara o Magdzie, mące, kluskach i zegarach, Kraków 1942.

Czapczyński T., Lekcja metodyczna: „, Glupi Franek” Konopnickiej, „Muzeum” 1922, z. 2, s. 123-150.

Czapczyński T., Marian Piechal, „Prace Polonistyczne” 1937, s. 109-154, odbitka: Łódź 1937.

Czapczyński T., Metodyka ćwiczeń stylistycznych w szkole powszechnej i średniej. Podręcznik dla nauczyciela, Lwów 1929.

Czapczyński T., Pamiętam... Poezje, Łódź 1938.

Czapczyński T., Pierwszy ustęp w klasie pierwszej szkoły średniej (cz. II), „Przyjaciel Szkoły” 1924, nr 14, s. 296-300.

Czapczyński T., Pomocnicze ćwiczenia stylistyczne, „Ruch Pedagogiczny” 1928, nr 1, s. 15-21; nr 2, s. 43-46; nr 3, s. 89-93.

Czapczyński T., Porównania jako materiał do ćwiczeń stylistycznych, „Szkoła i Wiedza” 1927/1928, z. 4, s. 155-166.

Czapczyński T., Przygotowawcze ćwiczenia stylistyczne w zakresie użycia przymiotnika, „Szkoła i Wiedza" 1927/1928, z. 1, s. 9-17.

Kształcenie Językowe 16 (26), 2018

(C) for this edition by CNS 
Czapczyński T., Twórczość powieściopisarska Józefa Weyssenhoffa (jednostronna analiza wewnętrznej konstrukcji), [w:] Sprawozdanie dyrekcji gimnazjum realnego żeńskiego Sióstr Urszulanek w Stanisławowie z prawem publiczności w myśl reskr. Min. W. i O. z 16 maja 1914, L. 18574 oraz Szkoly Pospolitej i Liceum 7-klasowego za rok szkolny 1913/14, Stanisławów 1914, s. 3-45.

Czapczyński T., Walerian Łukasiński, Stanisławów 1913.

Czapczyński T., Wypracowania piśmienne w świetle pogląów niemieckich (1911-1930). Karta $z$ historii zagadnienia, „Prace Polonistyczne” 1938, seria 2, s. 329-350.

Czapczyński T., Wypracowania piśmienne w świetle poglądów niemieckich (1911-1930). Tematy wypracowań, „Prace Polonistyczne” 1939, seria 3, s. 363-382, odbitka: Łódź 1939.

Czapczyński T., Ze studiów nad pieśnią o Piłsudskim, „Prace Polonistyczne” 1939, seria 3, s. 207-241, odbitka: Łódź 1939.

Dilthey W., Rozumienie, przeł. K. Krzemieniowa, [w:] Z. Kuderowicz, Dilthey, Warszawa 1987, s. 214-233.

Dziedzic A., Pichalska J., Świderska E., Drama na lekcjach języka polskiego w szkole średniej, Warszawa 1995.

Gaertner H., Ćwiczenia słownikowe w szkole powszechnej, Lwów 1927.

Gaertner H., Nauka o języku polskim. Wskazówki do samoksztatcenia ze słowniczkiem terminów gramatycznych i pomocniczych, Lwów 1927.

Gajak-Toczek M., Franciszek Próchnicki (1847-1911) — dydaktyk — edytor — badacz literatury, Łódź 2010.

Gajak-Toczek M., Franciszka Próchnickiego instrukcja programowa i metodyczna, „Acta Universitatis Lodziensis. Folia Litteraria Polonica" 2003, nr 6, s. 469-492.

Gajak-Toczek M., O budowaniu tożsamości narracyjnej uczniów poprzez działania dramowe na lekcjach języka polskiego w szkole średniej, [w:] Skoro i tak gram ... Edukacja kulturowa poprzez teatr, red. G. Tomaszewska, D. Szczukowski, Gdańsk 2009, s. 159-173.

Gajak-Toczek M., O metodach aktywizujacych (z doświadczenia nauczyciela praktyka), [w:] Problemy poznawania dzieła literackiego w szkole. Tekst, kontekst, znak, znaczenie, red. T. Świętosławska, Łódź 2001, s. 224-239.

Gajak-Toczek M., Propozycje wykorzystania technik dramowych na lekcjach języka polskiego w średnich szkołach zawodowych, Łódź 1994.

Gajak-Toczek M., Tadeusz Czapczyński. Pedagog — literaturoznawca — literat, Łódź 2017.

Klemensiewicz Z., Dydaktyka nauki o języku ojczystym. Zasady i zagadnienia, Warszawa 1928.

Komarnicki L., Stylistyka polska, Warszawa 1922.

Łoś J., Gramatyka polska, t. 1-3, Lwów 1922-1926.

Memoriat do Ministerstwa WRiOP w sprawie nauki języka polskiego w szkołach średnich, ,Język Polski” 1921, nr 2, s. 56-57.

Myrdzik B., Rola dramy w kształceniu polonistycznym, [w:] Wokół szkoły i nauczyciela: skrypt dla studentów filologii polskiej, red. H. Wiśniewska, J. Plisiecki, Lublin 1995, s. 43-54.

Nagajowa M., Ćwiczenia w mówieniu i pisaniu w klasach IV-VIII szkoły podstawowej, Warszawa 1977.

Nitsch K., Kilka stów o celach nauczania języka ojczystego, „Rocznik Pedagogiczny” 1, 1921, s. 190-194, przedruk [w:] Wybór prac z metodyki nauczania języka polskiego, red. B. Wieczorkiewicz, Warszawa 1964, s. 24-27.

Ogłoza E., Polański E., Szymik E., Drama na lekcjach języka polskiego w klasach IV-VIII, Kielce 1997.

Pankowska K., Drama - zabawa - myślenie, Warszawa 1990.

Pankowska K., Świtała W., Drama jako propozycja interpretacji utworów literackich, „Polonistyka” 1989, nr 10, s. 767-773.

Kształcenie Językowe 16 (26), 2018

(C) for this edition by CNS 
Prądy w nauczaniu języka polskiego, [praca zbiorowa], Warszawa 1908.

Program nauki w gimnazjach, Warszawa 1934.

Program nauki w publicznych szkołach powszechnych trzeciego stopnia z polskim językiem nauczania (tymczasowy), Lwów 1934

Próchnicki F., Wskazówki do nauki języka polskiego, Lwów 1885.

Próchnicki F., Wojciechowski K., Wypisy polskie dla szkót średnich (klasy IV-V), Lwów 1911.

Reiter M., Czytania polskie (klasy I-III), Lwów 1910-1912.

Rozwadowski J., O nauce języka ojczystego w szkołach i o rzeczach pokrewnych, „Język Polski” 1926, nr 1, s. 1-20.

Rudnicki M., Wykształcenie językowe w życiu i szkole, Warszawa-Poznań 1920.

Skoczylas L., Lektura powieści w szkole średniej, [w:] Sprawozdanie Dyrekcji c.k. Gimnazjum im. Franciszka Józefa we Lwowie za rok szkolny 1914, Lwów 1914, s. 27-32.

Skoczylas L., Referat Krakowskiej Sekcji Polonistów w sprawie nauczania języka polskiego w wyższych klasach szkoły średniej, [w:] Pamiętnik II Ogólnopolskiego Zjazdu Polonistów w Krakowie, Warszawa-Lwów 1931, s. 48-58.

Skwarczyńska S., Tadeusz Czapczyński (1884-1958), „Prace Polonistyczne” 1960, seria 16, s. 229 232.

Stylistyka Bally'ego. Wybór tekstów, przeł. U. Dembska-Prokop, Warszawa 1966.

Saussure F. de, Szkice z językoznawstwa ogólnego, przeł., wstęp i red. nauk. M. Danielewiczowa, Warszawa 2004.

Sylwetki lwowskich historyków literatury, red. J. Starnawski , Łódź 1997.

Szober S., Gramatyka w szkole średniej. Jej zadania, metoda, program, teoria i zakres wykkadu, „Wychowanie w Domu i Szkole” 1913, nr 3, s. 198-209; nr 4, s. 302-315; nr 5, s. 417-436.

Szober S., Pogląd na świat w odbiciu faktów językowych i wartości wychowawcze nauki gramatyki, „Rocznik Pedagogiczny” 1921, s. 194-213.

Szober S., Zasady nauczania języka polskiego w zakresie szkoty powszechnej i gimnazjum niższego, Lwów-Warszawa 1921.

Szober S., Znaczenie pedagogiczno-wychowawcze języka ojczystego jako przedmiotu wykładowego, „Nowe Tory” 1, 1911, z. 5, przedruk [w:] Wybór prac z metodyki nauczania języka polskiego, red. B. Wieczorkiewicz, Warszawa 1964, s. 18-23.

Szycówna A., Metodyka wypracowań, cz. 1. Podstawy psychologiczne i historyczne, Warszawa 1919.

Tenner J., Estetyka żywego słowa, Warszawa 1904.

Tenner J., Technika żywego stowa, Lwów-Warszawa 1906.

Trentowski B., Chowanna, czyli system pedagogiki narodowej jako umiejętności wychowania, nauki i oświaty, słowem wykształcenia naszej młodzieży, Poznań 1842.

Tync S., Gołąbek J., Poradnik metodyczny do „, Czytanek polskich” dla IV klasy szkót powszechnych pierwszego stopnia. Kurs A, Lwów-Warszawa 1936.

Tync S., Gołąbek J., Przewodnik metodyczny do „Czytanek polskich” dla IV klasy szkót powszechnych pierwszego stopnia. Kurs B, Lwów-Warszawa 1938.

Tync S., Gołąbek J., Przewodnik metodyczny do „Czytanek polskich” dla IV oddziału szkoły powszechnej, Lwów 1928.

Tync S., Gołąbek J., Przewodnik metodyczny do „Czytanek polskich” dla klas I, II gimnazjum, Lwów-Warszawa 1927-1928.

Vossler K., Studia stylistyczne, Warszawa 1972.

Way B., Drama w wychowaniu dzieci i młodzieży, Warszawa 1990.

Witerska K., Drama: techniki, strategie, scenariusze, Warszawa 2011.

Wojciechowski K., Szober S., Nawroczyński B., Wskazówki metodyczne do programu gimnazjum państwowego. Język polski (gimnazjum wyższe), Warszawa 1923.

Woroniecki J., Około kultu mowy ojczystej, Lwów-Warszawa 1925.

Kształcenie Językowe 16 (26), 2018

(C) for this edition by CNS 